\title{
Studies on Protein Nutrition of Papua New Guinea Highlanders: Nitrogen Balance and Hematological Studies ${ }^{1}$
}

\author{
Yoshiaki FuJITA, ${ }^{2}$ Toru RIKIMARU, ${ }^{2}$ Toyoko OKUDA, ${ }^{3}$ \\ Chigusa DATE, ${ }^{3}$ Naemi KaJIWARA, ${ }^{5}$ \\ Kyoko YANASE, ${ }^{3}$ and Hideo $\mathrm{KOISHI}^{3}$ \\ ${ }^{1}$ Nutrition Research Laboratory, Tokyo Metropolitan Institute of \\ Gerontology, 35-2 Sakaecho, Itabashi-ku, Tokyo 173, Japan \\ ${ }^{3}$ Faculty of the Science of Living, Osaka City University, \\ 459 Sugimoto-cho, Sumiyoshi-ku, Osaka 558, Japan \\ ${ }^{4}$ Department of Public Health, School of Medicine, Osaka City \\ University, I Asahimachi, Abeno-ku, Osaka 545, Japan \\ ${ }^{5}$ Kobe Women's College, 2-1 Aoyama, Suma-ku, Kobe 654, Japan
}

(Received January 20, 1982)

\begin{abstract}
Summary Studies were made in August 1978 on the N-balance and hematological characteristics of 18 men living in the village of Kalugaluvi (altitude: $1,500 \mathrm{~m}$ ) near Lufa, which is $60 \mathrm{~km}$ from Goroka, in the Eastern Highland Province of Papua New Guinea. The average daily protein intake on 3 consecutive days was $95.2 \pm 29.3 \mathrm{mgN} / \mathrm{kg}(35.2 \pm 10.7 \mathrm{~g}$ protein/day), and $32.6 \pm 18.7 \%$ of the total protein intake was in the form of animal proteins. The calculated nutritional value of the dietary protein, scored according to the $1973 \mathrm{FAO} / \mathrm{WHO}$ pattern, was $83.7 \pm 10.6$. Urinary and fecal $\mathrm{N}$ excretions during the same period were $81.9 \pm 18.7$ and $26.3 \pm 11.8 \mathrm{mgN} / \mathrm{kg}$, respectively, giving a nitrogen balance of $-13.5 \pm 24.9 \mathrm{mgN} / \mathrm{kg}$. From N-balance data on individuals, the $\mathrm{N}$-intake for maintenance of a zero $\mathrm{N}$-balance was estimated as $116.3 \pm 48.6 \mathrm{mgN}$ / $\mathrm{kg}$ (mean $95 \%$ confidence interval).

Hematological data showed normal or rather high values for hemoglobin $(16.90 \pm 1.05 \mathrm{~g} / 100 \mathrm{ml})$ and serum proteins $(8.05 \pm 0.40 \mathrm{~g} / 100 \mathrm{ml})$. The increased level of serum proteins was associated with an increased globulin level.
\end{abstract}

Key Words Papua New Guinea highlanders, protein nutrition, nitrogen balance, blood properties

1 This study was supported by Grant 304138 from the Ministry of Education, Science and Culture of Japan.

${ }^{2}$ 藤田美明, ${ }^{2}$ 力丸 徹, ${ }^{3}$ 奥田豊子, ${ }^{4}$ 伊達ちぐさ, ${ }^{5}$ 梶原苗美, ${ }^{3}$ 柳瀬恭子,

3 小石秀夫 
Interest in highlanders in Papua New Guinea was awakened by the report of Hipsley and Clements $(1)$ that these people are physically well developed although their food is meager in quantity and poor in quality. Many investigators (1-5) have reported that the daily protein intake of these people is less than $40 \mathrm{~g}$ and that most of the dietary protein is derived from customary vegetable foods.

Oomen(4) examined 23 highlanders and reported that they were in severe negative $\mathrm{N}$-balance of about $2 \mathrm{~g} / \mathrm{day}$, despite their well-developed physique. As a possible explanation for this finding, he suggested that intestinal flora may provide a significant amount of additional nitrogen. However, few studies have been made on the nitrogen balance of these highlanders, although there have been many reports focused on their protein intakes. Moreover, these reports scarcely mention utilization of ingested protein.

The primary object of the present study was 1) to extend the previous observations (1-5) on the dietary protein intake and nitrogen balance of the highlanders and 2) to elucidate the protein utilization of the highlanders based on N-balance studies and hematological observations.

Details of the village examined and its inhabitants and their lives, and results of the nutritional survey are reported elsewhere $(6,7)$.

\section{METHODS}

Subjects. The subjects examined were 18 healthy men of about 20 to 40 years of age; as they did not know their exact ages, ages were estimated as exactly as possible by a medical assistant working at the Medical Center in Lufa, on the basis of their physiological appearance, the genealogical tree of their family and written records of the province. The subjects gave normal values in urinary tests for sugar, protein, acetone bodies and urobilinogen. Their average body weight was $59.1 \pm 5.4 \mathrm{~kg}$ and their average height $158.3 \pm 5.4 \mathrm{~cm}$. Detailed individual data are shown in Table 1.

Collections and analyses of samples. To obtain as accurate experimental data as possible, we gave full explanations to the subjects and their families of the object and design of the experiment and the procedure for collection of urine and feces. The subjects were monitored by an investigator for two to three days of usual daily life with customary physical activity, behavior and diet from the time they got up in the morning until the time they retired at night.

Individual urine samples were collected in urine bottles for 24-hr periods during the experimental period. The bottles, which were marked with different colors, contained toluene as an antiseptic. The stools during the test period were marked with charcoal. Stools of individuals were pooled, mixed with a little acidified water, dried at 95 to $100^{\circ} \mathrm{C}$, weighed and finely ground.

Hematological tests were carried out on days 1, 3 and 5 of the experiment. Blood was withdrawn from the antecubital vein at 6:00 a.m., before breakfast, for measurements of the water content (8), hemoglobin concentration (9), and hematocrit (10) of whole blood and the total protein concentration(11) and albumin 
Table 1. Body size, age and nitrogen balance in Papua New Guinea highlanders on their usual diet.

\begin{tabular}{|c|c|c|c|c|c|c|c|}
\hline \multirow{2}{*}{ Code } & \multicolumn{3}{|c|}{ Subjects studied } & \multicolumn{4}{|c|}{ Nitrogen $^{a}$} \\
\hline & $\begin{array}{l}\text { Age }^{b} \\
(\text { y.o. })\end{array}$ & $\begin{array}{l}\text { Height } \\
(\mathrm{cm})\end{array}$ & $\begin{array}{l}\text { Weight } \\
\text { (kg) }\end{array}$ & Intake & $\begin{array}{l}\text { Urinary } \\
\qquad(\mathrm{mgN}\end{array}$ & $\begin{array}{l}\text { Fecal } \\
\text { g) }\end{array}$ & Balance \\
\hline 1 & 24 & 155.0 & 55.0 & 112.6 & 91.9 & 34.2 & -13.5 \\
\hline 2 & 25 & 166.0 & 62.0 & 87.4 & 66.5 & 13.2 & +7.7 \\
\hline 3 & 38 & 158.5 & 58.0 & 53.6 & 56.9 & 20.5 & -23.8 \\
\hline 4 & 20 & 166.0 & 62.1 & 98.7 & 88.4 & 24.6 & -14.3 \\
\hline 5 & 26 & 164.0 & 62.5 & 137.0 & 95.4 & 51.0 & -9.4 \\
\hline 6 & 40 & 159.0 & 59.0 & 95.9 & 73.3 & 28.7 & -6.1 \\
\hline 7 & 28 & 164.0 & 62.0 & 86.1 & 53.5 & 42.7 & -10.1 \\
\hline 8 & 35 & 154.5 & 55.5 & 75.9 & 80.8 & 36.0 & -40.9 \\
\hline 9 & 30 & 161.5 & 61.5 & 100.7 & 129.0 & 10.2 & -38.5 \\
\hline 10 & 39 & 153.0 & 59.0 & 134.2 & 78.2 & 20.3 & +35.7 \\
\hline 11 & 32 & 150.4 & 49.5 & 96.6 & 70.6 & 36.1 & -10.1 \\
\hline 12 & 28 & 159.5 & 60.5 & 68.3 & 77.2 & 12.0 & -20.9 \\
\hline 13 & 38 & 156.5 & 49.3 & 89.0 & 92.4 & 39.3 & -42.7 \\
\hline 14 & 33 & 162.5 & 65.5 & 66.3 & 67.6 & 14.7 & -16.0 \\
\hline 15 & 27 & 145.5 & 50.4 & 95.2 & 91.4 & 21.8 & -18.0 \\
\hline 16 & 26 & 157.6 & 59.0 & 170.0 & 102.4 & 20.2 & +47.4 \\
\hline 17 & 29 & 159.7 & 67.5 & 60.9 & 97.6 & 15.1 & -51.8 \\
\hline 18 & 33 & 157.0 & 66.0 & 75.3 & 60.7 & 32.1 & -17.5 \\
\hline Mean & & 158.3 & 59.1 & 95.2 & 81.9 & 26.3 & -13.5 \\
\hline SD & & 5.4 & 5.4 & 29.3 & 18.7 & 11.8 & 24.9 \\
\hline
\end{tabular}

${ }^{a}$ Values for $\mathrm{N}$-intake and urinary $\mathrm{N}$ are averages for 3 days and values for fecal $\mathrm{N}$ are for pooled samples obtained on the same 3 days. ${ }^{b}$ Estimated by the medical assistant at the Medical Center in Lufa.

concentration (12) of the serum. Values for globulin were calculated from results on total serum proteins and albumin, and the ratio of albumin to globulin (A/G ratio) was calculated.

All the foods the subjects ate were weighed exactly before and after cooking and remains after eating were also weighed. From these data, the weight of raw food eaten by individuals was calculated. The mean daily intake of food per capita reported previously (7) is shown again in Table 2 . The representative samples shown in Table 3 were collected, dried to constant weight at 95 to $105^{\circ} \mathrm{C}$ in Papua and transported to Japan for analysis. Nitrogen contents determined by the Kjeldahl method were used for estimations of nitrogen intake. The nitrogen contents of foods eaten other than those listed in Table 3 were calculated from recent standard tables (13) and other literature (14).

Some samples were analyzed in a provisional laboratory in Papua, but most Vol. 28, No. 4, 1982 
Table 2. Mean daily intake of foods per capita.

\begin{tabular}{lclc}
\hline \multicolumn{1}{c}{ Food group } & (g/day) & \multicolumn{1}{c}{ Food group } & (g/day) \\
\hline Potatoes & $1,120 \pm 260^{\mathrm{a}}$ & Fruits & $24 \pm 55$ \\
Cereals & $50 \pm 58$ & Sugar (sugar cane) & $84 \pm 148$ \\
Green leaves & $34 \pm 41$ & Fish (canned) & $13 \pm 18$ \\
Other vegetables & $49 \pm 60$ & Seeds and nuts & $1 \pm 3$ \\
Meat & $28 \pm 55$ & Egg & 0 \\
Oil (pig fat) & $45 \pm 49$ & Milk & 0 \\
\hline
\end{tabular}

${ }^{\text {a }}$ Mean \pm SD. Some standard deviations are large because some subjects did not eat the particular food during the experiment.

Table 3. Protein contents of representative and specific food samples from the test village in Papua New Guinea. ${ }^{a}$

\begin{tabular}{|c|c|c|c|}
\hline & Crude protein $(\%)$ & & Crude protein $(\%)$ \\
\hline Roots & & Animal foods & \\
\hline Sweet potato & 1.5 & Bird 1 & 21.6 \\
\hline Taro & 0.6 & Bird 2 & 24.2 \\
\hline Yam & 1.7 & Wild rat (Cuscus) & 22.4 \\
\hline Cassava & 0.9 & Wild rat (Rat) & 20.5 \\
\hline Cereals & & Larval Beetle & 10.1 \\
\hline Corn 1 & 4.5 & Cricket & 16.9 \\
\hline Corn 2 & 4.2 & Fruits & \\
\hline Corn 3 & 5.0 & Banana 1 & 1.6 \\
\hline Green leaves & & Banana 2 & 1.4 \\
\hline $1(\text { Lemu })^{b}$ & 4.5 & Papaya & 0.3 \\
\hline 2 (Kijho) & 4.9 & Nuts & \\
\hline 3 (Seka) & 4.4 & Nuts (Hary) & 10.0 \\
\hline 4 (Fagotabe) & 3.2 & Peanuts & 29.7 \\
\hline 5 (Kireme) & 3.9 & Mushroom & \\
\hline 6 (Hagaro) & 2.7 & Mushroom & 0.7 \\
\hline 7 (Vehada) & 1.8 & & \\
\hline 8 (Hore) & 1.2 & & \\
\hline
\end{tabular}

${ }^{a}$ Samples were collected, dried to constant weight at 95 to $105^{\circ} \mathrm{C}$ in Papua and transported to Japan for analyses. Nitrogen contents were determined by the Kjeldahl method. ${ }^{b}$ Native names.

were brought back to Japan as frozen or dried preparations. The nitrogen contents of the food, urine and feces were determined by the Kjeldahl method, and creatinine and creatine in the urine were measured by the Folin method as modified by $\operatorname{Koishi}(15)$. 
RESULTS AND DISCUSSION

\section{Energy intake}

The mean energy intake per day of the 18 healthy highlanders was $2,390 \pm 540$ $\mathrm{kcal}(40.4 \mathrm{kcal} / \mathrm{kg})$. This value accords well with their energy expenditure per day $(2,320 \pm 420 \mathrm{kcal}, 39.5 \mathrm{kcal} / \mathrm{kg})$ estimated from results of time studies. Details of these studies have been reported previously (7).

\section{Nitrogen intake}

The daily $\mathrm{N}$-intake of individuals varied widely from 53.6 to $170.0 \mathrm{mg} / \mathrm{kg}$, with a mean of $95.2 \pm 29.3 \mathrm{mgN} / \mathrm{kg}(35.2 \pm 10.7 \mathrm{~g}$ of protein/day). This value was higher than that reported by Oomen $(2,4)$ but lower than that given by Norgan et al. (5). Of the total protein intake, $32.6 \pm 18.7 \%$ was animal protein, mainly pork (about $80 \%$ ), with some canned fish, and small amounts of wild rat, birds and insects. The mean daily intake of foods per capita is shown in Table 2. The mean nutritional value of the dietary protein scored on the basis of the amino acid scoring pattern of $1973 \mathrm{FAO} / \mathrm{WHO}$ was $83.7 \pm 10.6$. The animal protein ratio was higher than that (15.2 to $22.8 \%, n=43$ ) for highlanders reported by Norgan et al. (5) though the score was comparable.

\section{Nitrogen balance study}

Results are shown in Table 1. The urinary nitrogen excretion of individuals was proportional to the $\mathrm{N}$-intake, but not the fecal nitrogen excretion. The mean value for urinary and fecal nitrogen excretions were $81.9 \pm 18.7$ and $26.3 \pm 11.8 \mathrm{mg} / \mathrm{kg}$, respectively. The subjects we examined showed higher urinary nitrogen levels than those reported by Oomen $(2,4)$, but slightly lower values of fecal $\mathrm{N}$ output. From these results the nitrogen balance was estimated as $-13.5 \pm 24.9 \mathrm{mgN} / \mathrm{kg}$ $(-0.789 \pm 1.427 \mathrm{gN} /$ day $)$. Although the mean balance for the subjects was slightly negative, three of the subjects maintained a positive balance. Oomen (4) found that all 23 subjects he examined had a negative $\mathrm{N}$-balance of about $2 \mathrm{gN} /$ day. Inoue et al. showed previously(16) that results of nitrogen balance studies are greatly affected by the dietary energy level. But the total energy intake was satisfactory not only in our subjects but also in those reported by Oomen. A possible explanation for the difference in nitrogen balance in these two surveys is the lower fecal $\mathrm{N}$ output of our subjects.

Values for the $\mathrm{N}$-balance of the 18 individuals are plotted against their $\mathrm{N}$ intakes in Fig. 1. The regression line is described by the equation $Y=0.624 X-72.5 \pm 30.3(n=18, r=+0.71, p<0.01)$, where $Y$ is the $\mathrm{N}$-balance $(\mathrm{mgN} / \mathrm{kg})$ and $X$ is the $\mathrm{N}$-intake $(\mathrm{mgN} / \mathrm{kg})$. The $\mathrm{N}$-intake for maintenance of $\mathrm{N}$ equilibrium in the 18 highlanders was calculated as $116.3 \pm 48.6 \mathrm{mgN} / \mathrm{kg}$. This value is comparable to the value $119.3 \pm 19.7 \mathrm{mgN} / \mathrm{kg}$ observed by Inoue et al. (16) in young Japanese men fed on a diet containing graded levels of vegetable protein with a maintenance energy level. The regression equation for the latter was

Vol. 28, No. 4, 1982 


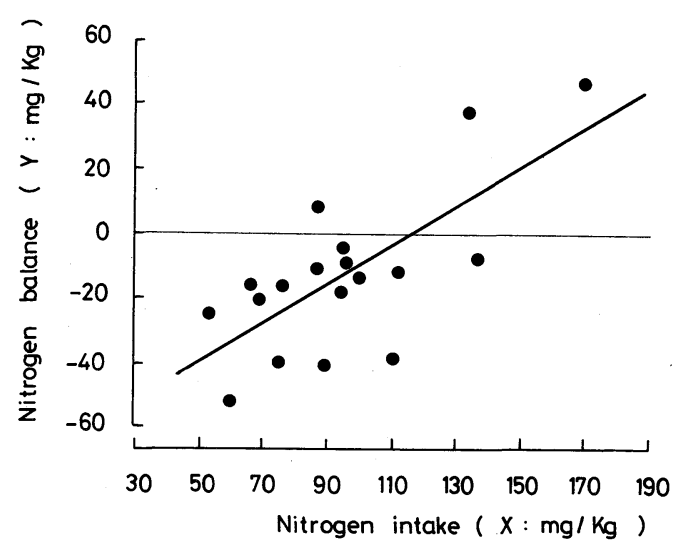

Fig. 1. Correlation between nitrogen intake and nitrogen balance in Papua New Guinea highlanders (male adults). Values are averages for three days for individuals on their customary diets. The regression equation was estimated as: $Y=0.624 \pm 0.306 X-72.5 \pm 30.3(n=18, r=+0.71, p<0.01)$, where $Y$ is the Nbalance $(\mathrm{mgN} / \mathrm{kg})$ and $X$ is the $\mathrm{N}$-intake $(\mathrm{mgN} / \mathrm{kg})$.

$Y=0.286 X-31.98 \pm 5.26(n=14, r=+0.80, p<0.01)$. There was no difference between the highlanders and Japanese men with respect to the nitrogen requirements for maintenance of $\mathrm{N}$ equilibrium. But comparison of the two regression equations showed that the $Y$-intercept and the slope of the line for the highlanders were twice those for the Japanese. These differences suggest that whole body protein metabolism in the highlanders differs from that in Japanese in response to dietary protein: i.e., the efficiency of utilization of dietary protein by the highlanders, as a nitrogen balance index, is more than twice that by Japanese.

The mean nitrogen balance for the 18 subjects was slightly negative. But the Nintake was, though widely varied in individuals, well within the range of that recomended by $1973 \mathrm{FAO} / \mathrm{WHO}$ to cover the maintenance needs of adults. Moreover, their daily energy intake covered the energy expenditures. If one considers only urinary $\mathrm{N}$ losses, all subjects except No's. 3, 8, 9, 12, 13, 14 and 17 would be in positive balance. Therefore, if they are in the range of $\mathrm{N}$-intake observed in this study, and besides, are not exposed to unusual stress in daily living, their health may be maintained on the marginal level of the normal range.

\section{Fecal analyses}

The results of fecal analyses are shown in Table 4. The highlanders excreted $498 \pm 257 \mathrm{mg}$ dry weight of feces per $\mathrm{kg}$ body weight per day $(29.0 \pm 14.2 \mathrm{~g} / \mathrm{day})$ containing $5.58 \pm 0.86 \%$ nitrogen. Accordingly, fecal N-excretion was $26.3 \pm 11.8$ $\mathrm{mgN} / \mathrm{kg}(1.58 \pm 0.74 \mathrm{~g} / \mathrm{day})$. This value was slightly less than that reported by Oomen ( 2.1 to $2.5 \mathrm{gN} /$ day) and considerably less than that reported by Luyken et al. (3). This low value for $\mathrm{N}$-output in the feces gave a less negative $\mathrm{N}$-balance than 
Table 4. Creatinine and creatine excretions into the urine and fecal dry weight of Papua New Guinea highlanders on their usual diet. ${ }^{\mathrm{a}}$

\begin{tabular}{|c|c|c|c|c|c|c|}
\hline \multirow{3}{*}{ Code } & \multicolumn{3}{|c|}{ Urine } & \multicolumn{3}{|c|}{ Feces } \\
\hline & \multicolumn{2}{|c|}{ Creatinine } & \multirow{2}{*}{$\begin{array}{l}\text { Creatine } \\
\text { (mg/day) }\end{array}$} & \multicolumn{2}{|c|}{ Dry weight } & \multirow{2}{*}{$\begin{array}{c}\text { Nitrogen } \\
(\%)\end{array}$} \\
\hline & (mg/day) & $(\mathrm{mg} / \mathrm{kg})$ & & (g/day) & $(\mathrm{mg} / \mathrm{kg})$ & \\
\hline 1 & 1,308 & 23.78 & 9 & 30.7 & 553 & 6.19 \\
\hline 2 & 1,690 & 27.26 & 103 & 23.0 & 371 & 5.21 \\
\hline 3 & 1,015 & 17.50 & 52 & 15.7 & 271 & 5.17 \\
\hline 4 & 1,266 & 20.39 & 18 & 30.0 & 483 & 5.09 \\
\hline 5 & 1,264 & 20.22 & 0 & 53.6 & 858 & 5.95 \\
\hline 6 & 1,585 & 26.86 & 4 & 35.0 & 593 & 4.84 \\
\hline 7 & 1,360 & 21.94 & 112 & 47.3 & 763 & 5.60 \\
\hline 8 & 1,330 & 23.96 & 8 & 54.3 & 978 & 3.68 \\
\hline 9 & 1,316 & 21.40 & 348 & 10.0 & 163 & 6.29 \\
\hline 10 & 1,197 & 20.29 & 56 & 16.3 & 276 & 7.30 \\
\hline 11 & 1,210 & 24.44 & 58 & 31.5 & 636 & 5.67 \\
\hline 12 & 1,269 & 20.98 & 56 & 10.7 & 177 & 6.77 \\
\hline 13 & 1,032 & 20.93 & 77 & 46.3 & 939 & 5.14 \\
\hline 14 & 1,395 & 21.30 & 62 & 15.3 & 234 & 6.28 \\
\hline 15 & 1,314 & 26.07 & 117 & 20.7 & 411 & 5.32 \\
\hline 16 & 1,491 & 25.27 & 60 & 20.0 & 339 & 5.95 \\
\hline 17 & 2,080 & 30.81 & 52 & 23.3 & 345 & 4.37 \\
\hline 18 & 1,040 & 15.76 & 49 & 37.7 & 571 & 5.61 \\
\hline Mean & 1,342 & 22.73 & 69 & 29.0 & 498 & 5.58 \\
\hline SD & 255 & 3.68 & 78 & 14.2 & 257 & 0.86 \\
\hline
\end{tabular}

${ }^{a}$ Values for creatinine and creatine are averages for 3 days and values for feces are for pooled samples obtained on the same 3 days.

that reported by others. The apparent digestibility of the dietary protein by the highlanders was calculated as $70.7 \pm 13.0 \%$, which is reasonable considering that most of the dietary protein was from vegetable foods.

\section{Creatinine and creatine excretions}

The highlanders excreted $1,342 \pm 255 \mathrm{mg} /$ day of creatinine and $69 \pm 78 \mathrm{mg} / \mathrm{day}$ of creatine in the urine. The creatinine index was $22.73 \pm 3.68$, which is within the normal range for Japanese. This value was lower than that expected from the welldeveloped muscles of the highlanders.

\section{Hematological analyses}

Results of hematological analyses are compared with normal values for Japanese (17) in Table 5. The water content of whole blood $(80.2 \pm 1.5 \%)$ was 
Table 5. Blood analyses for Papua New Guinea highlanders on their usual diet. ${ }^{\mathrm{a}}$

\begin{tabular}{|c|c|c|c|c|c|c|c|}
\hline \multirow{3}{*}{$\begin{array}{c}\text { Code } \\
1\end{array}$} & \multicolumn{3}{|c|}{ Whole blood } & \multicolumn{4}{|c|}{ Serum proteins } \\
\hline & \multirow{2}{*}{$\begin{array}{c}\begin{array}{c}\text { Water } \\
(\%)\end{array} \\
81.40\end{array}$} & \multicolumn{2}{|c|}{$\begin{array}{l}\mathrm{Ht} \\
(\mathrm{g} / 100 \mathrm{ml})\end{array}$} & $\begin{array}{c}\text { Total } \\
(\mathrm{g} / 100 \mathrm{ml})\end{array}$ & $\begin{array}{l}\text { Albumin } \\
(\mathrm{g} / 100 \mathrm{ml})\end{array}$ & \multicolumn{2}{|c|}{$\begin{array}{l}\text { Globulin }{ }^{\mathrm{b}} \mathrm{A} / \mathrm{G} \text { ratio } \\
(\mathrm{g} / 100 \mathrm{ml})\end{array}$} \\
\hline & & 46.7 & 16.60 & 8.01 & 4.35 & 3.66 & 1.19 \\
\hline 2 & 81.00 & 46.4 & 17.21 & 7.85 & 3.97 & 3.88 & 1.02 \\
\hline 3 & 79.78 & 52.0 & 18.00 & 7.73 & 3.39 & 4.34 & 0.78 \\
\hline 4 & 78.91 & 48.2 & 17.39 & 8.71 & 4.32 & 4.39 & 0.98 \\
\hline 5 & 81.66 & 43.8 & 16.16 & 7.33 & 3.48 & 3.85 & 0.90 \\
\hline 6 & 80.33 & 45.3 & 17.22 & 8.37 & 3.99 & 4.38 & 0.91 \\
\hline 7 & 82.36 & 42.5 & 15.23 & 8.19 & 3.89 & 4.30 & 0.90 \\
\hline 8 & 83.65 & 51.4 & 17.77 & 8.19 & 4.59 & 3.60 & 1.28 \\
\hline 9 & 79.15 & 52.6 & 16.38 & 8.14 & 4.01 & 4.13 & 0.97 \\
\hline 10 & 80.87 & 46.4 & 16.71 & 8.31 & 3.79 & 4.52 & 0.84 \\
\hline 11 & 79.81 & 45.4 & 16.20 & 7.70 & 3.81 & 3.89 & 0.98 \\
\hline 12 & 79.79 & 52.4 & 16.66 & 8.09 & 4.20 & 3.89 & 1.08 \\
\hline 13 & 80.45 & 41.2 & 14.41 & 7.29 & 3.46 & 3.83 & 0.90 \\
\hline 14 & 79.22 & 50.0 & 17.99 & 8.46 & 3.95 & 4.51 & 0.88 \\
\hline 15 & 78.45 & 45.8 & 16.78 & 7.61 & 3.71 & 3.90 & 0.95 \\
\hline 16 & 80.68 & 45.9 & 16.65 & 8.66 & 3.90 & 4.76 & 0.82 \\
\hline 17 & 79.09 & 48.7 & 18.16 & 8.06 & 4.24 & 3.82 & 1.11 \\
\hline 18 & 77.27 & 50.9 & 18.61 & 8.18 & 4.34 & 3.84 & 1.13 \\
\hline Mean & 80.22 & $47.5 * * *$ & $16.90^{* * *}$ & $8.05 * * *$ & $3.97 * * *$ & $4.08 * * *$ & $0.98^{* * *}$ \\
\hline SD & 1.51 & 3.4 & 1.05 & 0.40 & 0.33 & 0.34 & 0.13 \\
\hline \multicolumn{8}{|c|}{ Japanese normal values (male adults) } \\
\hline Mean & & $44.5^{2}$ & 14.8 & 7.67 & 4.18 & 3.49 & 1.21 \\
\hline SD & & 2.9 & 1.2 & 0.42 & 0.20 & 0.36 & 0.14 \\
\hline & & $(365)^{\mathrm{c}}$ & $(365)$ & (133) & (133) & (133) & (133) \\
\hline
\end{tabular}

${ }^{a}$ Blood was withdrawn at 6:00 a.m. before breakfast and values for individuals are averages for three samples taken on days 1,3 and $5 .{ }^{b}$ Values were calculated from values for total serum protein and albumin. ${ }^{\mathrm{c}}$ Numbers of subjects. ${ }^{* * *}$ Significantly different from the normal value for Japanese (17) at the level of $p<0.001$.

similar to that for Japanese, but the hematocrit $(47.5 \pm 3.3)$ and hemoglobin concentration $(16.90 \pm 1.05 \mathrm{~g} / 100 \mathrm{ml})$ were significantly higher than those for normal Japanese and those reported by Hornabrook et al. (18) for people in the Lufa area. Previously, Yoshimura (19) obtained significantly low values for the hematocrit and hemoglobin concentration in comprehensive studies on young Japanese men fed on a low-protein diet. Contrary to this, the highlanders on low-protein diet showed a rather high hematocrit and high hemoglobin concentration. A possible explanation for this is that these people are physiologically adapted to hypoxia, because the village where they have lived for many generations is about 1,500 to 
2,000 $\mathrm{m}$ above sea level and hard physical activity at this altitude results in a lowered alveolar $\mathrm{pO}_{2}$. The hemoglobin contents are consistent with the regression equation $(\mathrm{Hb} \mathrm{g} / 100 \mathrm{ml}=12.06+0.0007$ altitude in feet $)$ calculated from the relationship between the hemoglobin concentration and altitude by Malcolm (20). Thus these results are physiologically reasonable. However, it should be noted that the highlanders have been able to adapt to hypoxia even though they have low protein intakes.

Previously we observed a lower serum protein concentration in young Japanese men given a low-protein diet containing about the same amount of protein as that of the highlanders (21). However, the serum protein concentration of the highlanders was $8.05 \pm 0.40 \mathrm{~g} / 100 \mathrm{ml}$, which is significantly higher than the normal value for Japanese. Similar values were observed by Hornabrook et al. (18) for inhabitants of the Lufa area. Fractionation of serum protein showed that the albumin concentration was significantly low and the globulin concentration high, resulting in a significantly low ratio of albumin to globulin. The low level of serum albumin reflects the low intake of dietary protein to some extent, as in young Japanese men. Thus the level of total serum protein may be increased by a compensatory increase in the globulin fraction. An alternative explanation for the high globulin level is that since the subjects live in highly insanitary environments, the high level of serum globulin is a reflection of increased antibody production in response to prolonged infections. The serum albumin level was within the normal range, although it was significantly lower than that in Japanese. Thus, the lowered $\mathrm{A} / \mathrm{G}$ ratio was mainly due to the increased globulin level. The slightly low albumin level is consistent with the slightly negative $\mathrm{N}$ balance.

The findings described above show that despite their low protein intakes, the highlanders showed no serious abnormalities of the blood and were adapted to their environment. Their nitrogen balance was slightly negative, but results of regression analyses of the nitrogen balance indicated that the highlanders utilized ingested protein more efficiently than Japanese. The latter two findings require further examination.

The authors thank Professor H. Yoshimura of Kobe Women's College for helpful advice and discussion. They also thank Dr. M. Alpers, Director, and Dr. P. Heywood of the Institute of Medical Research, Papua New Guinea, for help in this study, and Mr. Y. Sato and Dr. J. Onno of the Department of Health, Papua New Guinea for facilitating the required research.

\section{REFERENCES}

1) Hipsley, E. H., and Clements, F. W. (1950): New Guinea Nutrition Survey Expedition, 1947. Canberra, Dept. External Terr.

2) Oomen, H. A. P. C. (1961): The nutrition situation in Western New Guinea. Trop. Geogr. Med., 13, 321-335.

3) Luyken, R., Luyken-Koning, F. W. M., and Pikaar, N. A. (1964): Nutrition studies in Vol. 28, No. 4, 1982 
New Guinea. Am. J. Clin. Nutr., 14, 13-27.

4) Oomen, H. A. P. C. (1970): Interrelationship of the human intestinal flora and protein utilization. Proc. Nutr. Soc., 29, 197-206.

5) Norgan, N. G., Ferro-Luzzi, A., and Durnin, J. V. G. A. (1974): The energy and nutrient intake and the energy expenditure of $204 \mathrm{New}$ Guinean adults. Philo. Trans. $R$. Soc. Lond. (Biol. Sci.), 268, 309-348.

6) Koishi, H., Okuda, T., Kajiwara, N., Date, C., and Yanase, K. (1979): Ecological aspects of Papua New Guinea Highlanders (A review). Ann. Rep. Sci. Living, Osaka City Univ., 27, 1-19.

7) Okuda, T., Kajiwara, N., Date, C., Yanase, K., Rikimaru, T., Fujita,Y., and Koishi, H. (1981): Nutritional status of Papua New Guinea highlanders. J. Nutr. Sci. Vitaminol., 27, 319-331.

8) Kuroda, K. (1969): Studies on Blood Water (in Japanese), Igakushoin, Tokyo.

9) Cannan, R. K. (1958): Proposal for a certified standard for use in hemoglobinometrysecond and final report. J. Lab. Clin. Med., 52, 471-476.

10) McGovern, J. J., Jones, A. R., and Steiberg, A. G. (1955): The hematocrit of capillary blood. New Engl. J. Med., 253, 308-312.

11) Gornall, A. G., Bardawill, C. J., and David, M. M. (1949): Determination of serum protein by means of the biuret reaction. J. Biol. Chem., 177, 751-766.

12) Rodkey, F. L. (1965): Direct spectrophotometric determination of albumin in human serum. Clin. Chem., 11, 478-487.

13) Japanese Food Composition Table (3rd ed.) (1963). Edited by the Science and Technology Agency, published by the Finance Ministry Printing Office, Tokyo, Japan.

14) Norgan, N. G., Durnin, J. V. G. A., and Ferro-Luzzi, A. (1979): The composition of some New Guinea foods. Papua New Guinea Agric. J., 30, 25-39.

15) Koishi, H. (1962): A critical examination on the Folin's method for determination of creatinine concentration in the urine. Osaka City Med. J., 8, 1-15.

16) Inoue, G., Fujita, Y., and Niiyama, Y. (1973): Studies on protein requirements of young men fed egg protein and rice protein with excess and maintenance energy intakes. J. Nutr., 103, 1673-1687.

17) Sasaki, M., Kitamura, M., Ueda, N., and Nakayama, T. (1972): The Sampling of Human Body Constituents-Blood (in Japanese), Kodansha, Tokyo.

18) Hornabrook, R. W., Crane, G. G., and Stanhope, J. M. (1974): Karkar and Lufa: an epidemiological and health background to the human adaptability studies of the International Biological Programme. Philos. Trans. R. Soc. Lond. (Bilo. Sci.), 268, 293-308.

19) Yoshimura, H. (1972): Physiological effect of protein deficiency with special reference to evaluation of protein nutrition and protein requirements, in World Review of Nutrition and Dietetics, Vol. 14, Karger, Basel, pp. 100-133.

20) Malcolm, L. A. (1970): Growth and development in New Guinea-A study of the Bundi people of the Madang District. Madang, Inst. Human Biol., Papua New Guinea Institute of Human Biology, Monograph Series No. 1, pp. 19-29.

21) Fujita, Y., Yoshimura, Y., and Inoue, G. (1978): Effect of low-protein diets on free amino acids in plasma of young men: Effect of protein quality with maintenance or excess energy intake. J. Nutr. Sci. Vitaminol., 24, 297-309. 